\title{
Seasonal variations in the biochemical composition of muscle and liver of marine fishes, Gazza achlamys and Ariomma indica from Visakhapatnam coast, South India.
}

\section{Siva Prasad K. ${ }^{1 *}$, Prasad. N. V. ${ }^{2}$, Ch. Venkateswarlu ${ }^{1}$}

${ }^{1}$ Department of Zoology, P.B. Siddhartha College of Arts and Science, Vijayawada-520010, Andhra Pradesh, India. ${ }^{2}$ Division of Marine Biology, Department of Zoology, Andhra University, Visakhapatnam, India.

Received: 2017-05-22; Accepted: 2017-05-29

Available online: 1 st June 2017

\begin{abstract}
Seasonal variations in biochemical constituents were observed in muscle and liver of two marine fishes i.e. Gazza acblamys and Ariomma indica. The result indicated that muscle proteins are low in monsoon season in $A$. indica and in all seasons in G. acblamys. When compared to muscle, carbohydrate and lipids levels are very high in liver tissue of $A$. indica. Whereas there is a slight difference in G. acblamys. It is well understood from the current study that each habitat group of fishes has its own nutritional value parameters with sense to their different food preferences. This shows the mobilization of biochemical constituents in body tissues during different seasons. Based on current finding, it is concluded that G. acblamys and A. indica are the good source of protein, carbohydrates and lipids.
\end{abstract}

Keywords: Marine fishes; Gazza acblamys; Ariomma indica; Biochemical constituents; Seasonal variation.

\section{Introduction}

Food is an important item next to air and water for the maintenance of the process of life on the earth. Fishes plays a major role in human nutrition. Biochemical constituents, particularly, proteins, carbohydrates, lipids, vitamins and minerals, make fish a nutritious food. The contribution of food fish to the total global animal protein in 1996 was 16.0 , and $14.7 \%$ in 2005 . In 2013 , fish provided 3.1 billion people with almost $20 \%$ of their intake of animal protein. India is a major fish producing country. The two million Sq.km Indian EEZ abounds in rich marine flora and fauna. These include a wide variety of commercially important finfish, crustaceans and mollusks.

Investigations regarding the biochemical composition of the fish and fish products have been initiated as early as $19^{\text {th }}$ century (Saha and Guha, 1940) ${ }^{1}$. After $19^{\text {th }}$ century several worldwide investigations were made on biochemical composition of fish. Noteworthy contributions are those of George et al., (1966) $)^{2}$ on the function of lipid composition in animal body; Sivani $(1994)^{3}$ on the chemical composition in different species of estuarine fishes. Rao and Rao (2002) ${ }^{4}$ studied the variations in biochemical composition of Glossogobius giuris from Gosthani estuary. Palace et al., (2003) 5 investigated the biochemical effects of dietary exposure to polybrominated diphenyl ethers in juvenile lake trout, Salvelinus namaych. Vaulyeva et al., $(2004)^{6}$ studied the lipid concentration and lipoprotein density of two-year

\section{*Corresponding Author:}

Dr. K. Siva Prasad,

Department of Zoology,

P.B. Siddhartha College of Arts and Science,

Vijayawada-520010, Andhra Pradesh, India. old female rainbow trout at the spawning period. Zaboukas and Miliou $(2006)^{7}$ worked on biochemical composition of Atlantic bonito at different stages of maturity. Sobha et al., $(2007)^{8}$ investigated the effect of toxicant stress on fish biochemical concentration in exposed fish. Douglas et al., (2008) ${ }^{9}$ observed the role of phospholipids in nutrition and metabolism of teleost fish.

Many of the fishes exhibit considerable seasonal changes in their composition due to changes in the environmental conditions such as availability of nutrients, pollution of coastal seawaters and fluctuations in hydrographic and oceanographic features. Hence, continuous monitoring of changes in the biochemical composition of different species is required. In the present study, the major biopolymers i.e., proteins, carbohydrates and lipids in muscle tissue and liver tissues are studied with respect to different seasons in Gazza achlamys and Ariomma indica. Seasons like pre-monsoon includes the calendar months March, April, May and June. Monsoon season includes July, August, September and October and post-monsoon comprising of November, December, January and February months.

\section{Materials and Methods}

To find out the concentrations of proteins, carbohydrates and lipids in demersal fish, Gazza achlamys and Ariomma indica, samples were collected

E-mail: katuruspanu@gmail.com 
at regular seasonal intervals for two years from Visakhapatnam fishing harbor and F.S.I vessels. In the laboratory, they were thoroughly cleaned with running tap water and the excess water was removed with blotting paper. After recording the necessary morphometric and meristic characters of the fish collected from the study area, the specimens were dissected immediately to avoid decomposition. Muscle samples were removed without skin; liver was removed separately from fish samples. The tissue was kept in hot air oven at $60^{\circ} \mathrm{C}$ for about a week to dry the material. After drying the tissue samples were pulverized and ground into a fine powder with the help of a porcelain mortar. The powder was preserved in desiccators for later use. Individually weighed powder samples were used for the quantitative estimation of proteins, carbohydrates and lipids in tissue. All the chemicals used were of analar grade.

The protein content of the muscle tissue was estimated by following Lowry's method (Lowry et al., 1951) ${ }^{10}$ and Carbohydrates by following calorimetric method (Dubois et al., 1956) ${ }^{11}$. The total lipids were extracted from the dry tissues, by following the method of Folsch et al., (1957) ${ }^{12}$. All the samples were taken in triplicates and the concentrations were given as percentage of dry weight of the tissue.

\section{Results}

The results of the biochemical composition of muscle tissue and liver of the fish, Gazza achlamys (Jordan \& Starks) and Ariomma indica (Day) from the study area have given in Table 1-4.

\section{Proteins:}

Protein is the most important and complex group of biological materials, as they form the chief nitrogenous constituents of the tissues of the body. Proteins serve as structural components as biocatalysts, as hormones and as depositors for the genetic information i.e characteristic of species. These are colloidal in nature, non-diffusible and contain high molecular weights.

During the year 2014-2015, the maximum protein content in muscle of $A$. indica occurred as 0.272 $(\mathrm{mg} / \mathrm{g})$ in post-monsoon period and minimum $(0.179 \mathrm{mg} / \mathrm{g})$ in monsoon season. In the year 20152016 also having maximum protein content $(0.341 \mathrm{mg} / \mathrm{g})$ in post-monsoon and minimum $(0.186 \mathrm{mg} / \mathrm{g})$ in monsoon season (Table 1$)$. While the maximum protein content in muscle of G. achlamys was observed as $0.246(\mathrm{mg} / \mathrm{g})$ during the post-monsoon and minimum $0.173(\mathrm{mg} / \mathrm{g})$ in monsoon season in the year 2014-15. In the year 2015-16, high protein content $0.231(\mathrm{mg} / \mathrm{g})$ was encountered in monsoon and minimum value as $0.196(\mathrm{mg} / \mathrm{g}$ ) during the pre-monsoon (Table 2).

Table 1: Protein, Carbohydrates and Lipids content in muscle of Ariomma indica.

\begin{tabular}{lcccccc}
\hline \multirow{2}{*}{ Season } & \multicolumn{2}{c}{ Protein $(\mathrm{mg} / \mathrm{g})$} & \multicolumn{2}{c}{ Carbohydrates $(\mathrm{mg} / \mathrm{g})$} & \multicolumn{2}{c}{ Lipids $(\mathrm{mg} / \mathrm{g})$} \\
\cline { 2 - 7 } & $\mathbf{2 0 1 4 - 1 5}$ & $\mathbf{2 0 1 5 - 1 6}$ & $\mathbf{2 0 1 4 - 1 5}$ & $\mathbf{2 0 1 5 - 1 6}$ & $\mathbf{2 0 1 4 - 1 5}$ & $\mathbf{2 0 1 5 - 1 6}$ \\
\hline Pre-monsoon & 0.196 & 0.238 & 0.031 & 0.047 & 0.036 & 0.029 \\
Monsoon & 0.179 & 0.186 & 0.056 & 0.026 & 0.052 & 0.047 \\
Post-monsoon & 0.272 & 0.341 & 0.029 & 0.039 & 0.048 & 0.065 \\
\hline
\end{tabular}

Table 2: Protein, Carbohydrates and Lipids content in muscle of Gazza achlamys.

\begin{tabular}{lcccccc}
\hline \multirow{2}{*}{\multicolumn{1}{c}{ Season }} & \multicolumn{2}{c}{ Protein $(\mathrm{mg} / \mathrm{g})$} & \multicolumn{2}{c}{ Carbohydrates $(\mathrm{mg} / \mathrm{g})$} & \multicolumn{2}{c}{ Lipids $(\mathrm{mg} / \mathrm{g})$} \\
\cline { 2 - 7 } & $\mathbf{2 0 1 4 - 1 5}$ & $\mathbf{2 0 1 5 - 1 6}$ & $\mathbf{2 0 1 4 - 1 5}$ & $\mathbf{2 0 1 5 - 1 6}$ & $\mathbf{2 0 1 4 - 1 5}$ & $\mathbf{2 0 1 5 - 1 6}$ \\
\hline Pre-monsoon & 0.187 & 0.196 & 0.021 & 0.028 & 0.020 & 0.035 \\
Monsoon & 0.173 & 0.231 & 0.019 & 0.045 & 0.032 & 0.041 \\
Post-monsoon & 0.246 & 0.216 & 0.047 & 0.039 & 0.029 & 0.031 \\
\hline
\end{tabular}

Table 3: Protein, Carbohydrates and Lipids content in liver of Ariomma indica.

\begin{tabular}{lcccccc}
\hline \multirow{2}{*}{ Season } & \multicolumn{2}{c}{ Protein $(\mathrm{mg} / \mathrm{g})$} & \multicolumn{2}{c}{ Carbohydrates $(\mathrm{mg} / \mathrm{g})$} & \multicolumn{2}{c}{ Lipids $(\mathrm{mg} / \mathrm{g})$} \\
\cline { 2 - 7 } & $\mathbf{2 0 1 4 - 1 5}$ & $\mathbf{2 0 1 5 - 1 6}$ & $\mathbf{2 0 1 4 - 1 5}$ & $\mathbf{2 0 1 5 - 1 6}$ & $\mathbf{2 0 1 4 - 1 5}$ & $\mathbf{2 0 1 5 - 1 6}$ \\
\hline Pre-monsoon & 0.562 & 0.634 & 0.280 & 0.385 & 0.429 & 0.621 \\
Monsoon & 0.697 & 0.397 & 0.312 & 0.269 & 0.476 & 0.523 \\
Post-monsoon & 0.735 & 0.486 & 0.397 & 0.327 & 0.725 & 0.565 \\
\hline
\end{tabular}

Table 4: Protein, Carbohydrates and Lipids content in liver of Gazza achlamys.

\begin{tabular}{lcccccc}
\hline \multirow{2}{*}{ Season } & \multicolumn{2}{c}{ Protein $(\mathrm{mg} / \mathrm{g})$} & \multicolumn{2}{c}{ Carbohydrates $(\mathrm{mg} / \mathrm{g})$} & \multicolumn{2}{c}{ Lipids $(\mathrm{mg} / \mathrm{g})$} \\
\cline { 2 - 7 } & $\mathbf{2 0 1 4 - 1 5}$ & $\mathbf{2 0 1 5 - 1 6}$ & $\mathbf{2 0 1 4 - 1 5}$ & $\mathbf{2 0 1 5 - 1 6}$ & $\mathbf{2 0 1 4 - 1 5}$ & $\mathbf{2 0 1 5 - 1 6}$ \\
\hline Pre-monsoon & 0.434 & 0.612 & 0.264 & 0.317 & 0.294 & 0.392 \\
Monsoon & 0.397 & 0.473 & 0.226 & 0.325 & 0.312 & 0.287 \\
Post-monsoon & 0.486 & 0.516 & 0.418 & 0.512 & 0.344 & 0.413 \\
\hline
\end{tabular}


Overall, the maximum protein content in the liver of $A$. indica observed as $0.735(\mathrm{mg} / \mathrm{g})$ during the post-monsoon season (2014-2015) and low (0.397 mg/g) in monsoon (2015-2016) (Table 3). While in the liver of $G$. achlamys, the maximum value $0.612 \mathrm{mg} / \mathrm{g}$ was observed in pre-monsoon season in 2015-2016 and minimum protein content $(0.397 \mathrm{mg} / \mathrm{g})$ during the monsoon season in 20142015 (Table 4).

\section{Carbohydrates:}

Carbohydrates are basic substances of protoplasm and involved in the storage and release energy. They defined chemically as aldehyde or ketone derivatives of the higher polyhydric alcohols or as compounds which yield these derivatives on hydrolysis. Glucose, fructose, mannose, sucrose, galactose, maltose, lactose, and glycogen are the important carbohydrates in the animal cells.

In $A$. indica, overall muscle carbohydrate shows high $(0.056 \mathrm{mg} / \mathrm{g})$ during monsoon season in 2014-2015 and low $(0.026 \mathrm{mg} / \mathrm{g})$ in the same season during the year 2015-16 (Table 1). In 20142015 , maximum value of carbohydrate $0.056 \mathrm{mg} / \mathrm{g}$ was observed in the muscle of $A$. indica during the monsoon season and low $0.029 \mathrm{mg} / \mathrm{g}$ during the post-monsoon season. Decrease in carbohydrate level as $0.026(\mathrm{mg} / \mathrm{g})$ during the year 2015-2016, in the season of monsoon and raised as $0.047(\mathrm{mg} / \mathrm{g})$ in pre-monsoon season.

The carbohydrate level in muscle of $G$. achlamys observed maximum $(0.047 \mathrm{mg} / \mathrm{g})$ in post-monsoon season and minimum $0.019 \mathrm{mg} / \mathrm{g}$ during monsoon season in the year 2014-2015. While the maximum carbohydrate value as $0.045(\mathrm{mg} / \mathrm{g})$ occurred in monsoon season and minimum value as 0.028 $(\mathrm{mg} / \mathrm{g})$ encountered in the season of pre-monsoon during the year 2015-2016 (Table 2).

In the liver of $A$. indica, carbohydrate observed as maximum $0.397(\mathrm{mg} / \mathrm{g})$ in the season of postmonsoon and minimum as $0.280(\mathrm{mg} / \mathrm{g})$ in the pre-monsoon season in 2014-2015. While in the year 2015-2016, the carbohydrate level increased during the pre-monsoon $(0.385 \mathrm{mg} / \mathrm{g})$ and decreased $(0.269 \mathrm{mg} / \mathrm{g})$ in the monsoon period (Table 3).

The carbohydrate content in the liver of G. achlamys was observed maximum in post-monsoon $(0.418$ $\mathrm{mg} / \mathrm{g})$ and minimum (0.226 $\mathrm{mg} / \mathrm{g})$ during the monsoon season in 2014-2015. While the maximum carbohydrate $0.512(\mathrm{mg} / \mathrm{g})$ occurred in post-monsoon season and minimum as 0.317 $(\mathrm{mg} / \mathrm{g})$ encountered in pre-monsoon in 2015-2016 (Table 4).

\section{Lipids:}

Lipids are organic substances insoluble in water, but soluble in organic solvents. They form important dietary constituents because their high calorific value and fat-soluble vitamins and essential fatty acids contained in them. They are present in the cytoplasm as well as the cell wall and also in the specialized areas of the body as deposits of fat.

The maximum Lipid content in the muscle of A. indica occurred as $0.052(\mathrm{mg} / \mathrm{g})$ during the monsoon period and minimum as $0.036(\mathrm{mg} / \mathrm{g})$ in the pre-monsoon season during the year 20142015. While in 2015-2016, increased the lipid level as $0.065(\mathrm{mg} / \mathrm{g})$ in post monsoon and decreased as $0.029(\mathrm{mg} / \mathrm{g})$ during pre-monsoon season. When compared all the seasons during the study period of two years, the lipid levels raised $(0.065 \mathrm{mg} / \mathrm{g})$ in post-monsoon during the year 2015-2016 (Table $1)$.

In $G$. achlamys, lipid levels in the muscle increased as $0.032(\mathrm{mg} / \mathrm{g})$ in monsoon and decreased as $0.020(\mathrm{mg} / \mathrm{g})$ in pre-monsoon season during the year 2014-2015. While lipid content increased as $0.041(\mathrm{mg} / \mathrm{g})$ in monsoon season and decreased to $0.031(\mathrm{mg} / \mathrm{g})$ in post-monsoon in 2015-2016 (Table 2).

The maximum value of Lipid content in the liver of $A$. indica occurred as $0.725(\mathrm{mg} / \mathrm{g})$ during the post-monsoon season and minimum value occurred as $0.429(\mathrm{mg} / \mathrm{g})$ during the pre-monsoon season in the period of 2014-2015. While in the year 2015-2016, the lipid level increased as 0.621 $(\mathrm{mg} / \mathrm{g})$ in the season of pre-monsoon and decreased to $0.523(\mathrm{mg} / \mathrm{g})$ during the monsoon season (Table 3).

The lipid content value in the liver of $G$. achlamys occurred a maximum value of $0.344(\mathrm{mg} / \mathrm{g})$ during the post-monsoon season and minimum values occurred as $0.294(\mathrm{mg} / \mathrm{g})$ in pre-monsoon season in the period of 2014-2015. While in the year 20152016, maximum value occurred as $0.413(\mathrm{mg} / \mathrm{g})$ in the season of post-monsoon and minimum values encountered as $0.287(\mathrm{mg} / \mathrm{g})$ during the monsoon season (Table 4).

\section{Discussion and Conclusion}

Generally, fish is considered as a very good source of animal protein. The importance of fish in the diet is due to not merely to the percentage of protein it contains, but to the amino acid makeup of the protein and its availability to the system. Recent knowledge demonstrates that the biological value of food protein is dependent on the amino acid composition. 
The present study concentrates on the estimation of protein, carbohydrate and lipid levels in muscle and liver of $G$. achlamys and $A$. indica during the post-monsoon, monsoon and pre-monsoon periods of two years i.e. from 2014 to 2016.

It was already reported that changes in the composition of biochemical constituents of the biota vary not only with environmental changes, but also with seasons (Ravisankar Pisca and Sarala Waghray, 1989; Sowmyashree Shetty et al., 2013; Rajendra Shejwal et al., 2014; Nadia Ullah et al., 2016) ${ }^{13-16}$. Such changes have also been attributed to various physiological and other factors like maturation, spawning, feeding etc. (Jacquot, 1961) ${ }^{17}$. Saha and Guha $(1940)^{18}$ reported that the chemical composition is dependent on age, sex, habitat and seasons. In tropical countries, comparatively little is known about the chemical composition of marine fishes excepting for a few works like those of Venkataramana and Chari $(1951)^{19}$ and Chidambaram et al., (1952) ${ }^{20}$. Hornung et al., (1994) $)^{21}$ worked on distribution and composition of fatty acids in muscle lipids of inshore fish and deep-water sharks from the eastern Mediterranean. Jeong et al., (1998)22 observed the Seasonal variation in lipid class and fatty acid composition of Korean fish. Clavijo et al., $(1999)^{23}$ worked on preliminary study of lipid content and fatty acid composition in the spot tail pinfish, Diplodus bolbrooki. Wang et al., (2002)24 studied the biochemical composition and its prediction model of red drum, Sciaemps ocellatus. Kamler (2003) ${ }^{25}$ made investigations on the chemical composition of muscle, liver and foot of Notothenioids. Wagner et al., (2004) ${ }^{26}$ studied the dietary fatty acid composition affects the repeat swimming performance of Atlantic salmon in seawater.

Investigations regarding the protein contents in fish and fish products were estimated as early as $19^{\text {th }}$ century. Saha and Guha (1939) ${ }^{27}$ have estimated the protein content of 24 different varieties of fresh water fish in Bengal. Sivani $(1994)^{3}$ and others reported that protein content was more in fishes during early summer and winter months corresponding to their maturity stages. During maturity stages, gonads get studded with proteins as well as fat and therefore the muscles generally contain relatively meager amount of protein and fat.

According to Satti Reddy $(1992)^{28}$, the fall in the protein content is due to a fall in the rate of feeding, because of scarcity of food material, especially during monsoon months due to turbidity and other ecological factors. In the present study, such observations have been made regarding silver bellies (Gazza achlamys) and Indian drift fish (Ariomma indica) of the study area. During monsoon months, due to lowering in $\mathrm{pH}$, fluctuations in salinity and siltation resulted from fresh water discharge; most of the fishes were not only deprived of food material but also affected with diseases. Because of diseases, much of the energy might have been utilized for recovery and protection.

A critical appraisal of the observations indicates that the carbohydrates as energy reserves are comparatively insignificant in aquatic animals as mentioned by Love $(1970)^{29}$. In the present study, the percentage of carbohydrates of the muscle and lipids of the muscle was very low when compared with liver carbohydrates and lipids of the liver in A. indica and G. achlamys. While the percentage of proteins and lipids of the liver was very high when compare with muscle proteins and lipids in A. indica and G. achlamys.

Satti Reddy (1992) 28 and Sivani (1994) ${ }^{3}$ reported that percentage of protein was more in early summer and winter, which corresponds to the maturing stage of the fishes. During maturity, the gonads get studded with proteins and fat and hence generally the muscle contains comparatively less proteins and fat. Similar observations were made in the present study. George et al., (1966) ${ }^{30}$ reported that lipids are present in the body in the form of non-calorific metabolic proteins. According to Hickling (1947) ${ }^{31}$ lipid content is directly related to the intensity of feeding.

It has been observed that lipid content was more in the fish $A$. indica, the season may be with favorable conditions food material might have produced abundantly that is needed for fast growth and rich in biochemical constituents. Chemical composition of fish is affected by environmental conditions and there are considerable differences in the chemical composition of reared and wild populations (Ehrlich, 1974) ${ }^{32}$

Overall, the percentage of the biochemical constituents (i.e., proteins, carbohydrates and lipids) in the fish was more. In a Swedish research project, extensive trail was made to examine the usefulness of biochemical and physiological parameters as indicators of health of fish exposed to Bleached Kraft Mill Effluents. In an introductory laboratory study, the long-term effects of BKME on the carbohydrate metabolism and hepatic xenobiotic biotransformation enzyme in a four-horn sculpin (Myoxecephalus quadricornis) were investigated by Anderson and May (1979) ${ }^{33}$.

From table 1-4 it can be read that the proteins in the post-monsoon season maximum protein content value in muscle of $A$. indica occurred as $0.272 \mathrm{mg} / \mathrm{g}$ in the year 2014-2015, and in 20152016 was $0.341 \mathrm{mg} / \mathrm{g}$. In the same fish, maximum protein content value in liver in the post-monsoon season occurred as $0.735 \mathrm{mg} / \mathrm{g}$ during the year 
2014-2015, and in 2015-2016 high value occurred as $0.634 \mathrm{mg} / \mathrm{g}$ during the pre-monsoon season. In the case of carbohydrates in the muscle of A. indica, maximum values $(0.397 \mathrm{mg} / \mathrm{g})$ occurred in the post-monsoon season during the year 2014-2015 and in 2015-2016 maximum values $(0.385 \mathrm{mg} / \mathrm{g}$ ) encountered in the pre-monsoon season. In the case of lipid values in liver is high $(0.725 \mathrm{mg} / \mathrm{g})$ in post monsoon season during the year 2014-2015 when compare with year 2015-2016 the maximum value $(0.621 \mathrm{mg} / \mathrm{g})$ occurred in pre-monsoon season. All these observations are in strong occurrence with many similar studies by others from elsewhere. Sivakami et al., (1994) ${ }^{34}$ reported that there was a marked decrease in protein, carbohydrates, and lipid contents in fresh water fish, Mystus vittatus exposed to Chromium. They observed that the protein content decreased quite markedly in the exposed fish. The same was true for the carbohydrate content also, whereas the decrease was not so significant in the lipid content. Reddy and Rao (1985) ${ }^{35}$ also observed a decrease in the carbohydrate level in prawns exposed to phosphamiolon. They observed that there is a consequence of high demand for energy during stress conditions followed by decreased food intake, the stored energy like lipid may be readily used to meet the energy demand.

From the above discussion, it is evident that these fishes are of good nutritive value, but may be sometimes infected with parasites during different seasons which hamper their growth rate. The dietary constituents affect the biochemical nature of fish tissues. Davis et al., (1999) ${ }^{36}$ stated that the supplementary diet of triglycerides reduces excessive lipid deposition in fish and exception of high lipid diet may result in poor performance of fish. Olsen et al., (1999) ${ }^{37}$ worked on Arctic charr (Salvelinus alpinus) fed on linseed oil and soyabean lecithin, showed epithelial damage and lipid droplets in intestinal lumen with increased levels of lipid. Bell et al., (1999) ${ }^{38}$ worked on liver pathology of Scopthalmus maximus, which showed increased lipid fatty acid composition and decreased poly unsaturated fatty acid.

Gunsekera et al., (2001) ${ }^{39}$ observed that chemical changes in proximate composition total and free amino acid and fatty acid content in fed and starved trout cod resulted in lowered levels of protein and lipid. Abdullahi (2001) ${ }^{40}$ made investigation on carbohydrate, lipid and protein levels in $C$. nigrodigutatus, $B$. fitamentosus and A. occidentalis reveal that protein contents are generally high in 3 species. Mourente and Dick $(2002)^{41}$ showed increased hepatocyte fatty acid with dietary vegetable oils supplemented in fish feed. Kirchner et al., (2003) ${ }^{42}$ studied the low level of dietary protein is associated with reduced hepatic gluconeogenic enzyme resulting in hyper glycaemia in rainbow trout (Oncorbynchus mykiss).
Environmental conditions also affect biochemical constituents of fish. Southgate et al., (1994) ${ }^{43}$ made extensive study on the growth and biochemical composition of cultured seabass and reported a decline of total lipid and carbohydrate contents. Carpene et al., (1998) 44 illustrated the biochemical differences in lateral muscle of wild and farmed gilthead seabream (Sparus aurata) in which protein yields are significantly higher in wild fish stating that the environmental conditions influenced the biochemical composition of lateral muscle. Izquierdo et al., (2003) ${ }^{45}$ worked on dietary lipid sources for seabream and seabass: growth performance, tissue composition and flesh quality. Ingermann et al., (2001) ${ }^{46}$ stated the protein content and inorganic phosphate content of seminal plasmas are less than those of corresponding blood plasma or ovarian fluid in Chinook salmon. Mourente et al., $(2001)^{47}$ stated that ovary lipid content increased significantly from immature to spawning stage but liver and muscle lipids did not show a major depletion during maturation in northern bluefintuna (Thunnus thynnus). Sebetes et al., (2003) ${ }^{48}$ stated that the total lipid content increased over the course of development is high in juveniles of three mesopelagic fishes. Vasualyeva et al., (2004) ${ }^{49}$ stated that there is gradual decrease in lipid concentration in lipoproteins of low density and increase in lipoproteins of high density towards the spawning period in two year ld female rainbow trout in an annual cycle. Zaboukas et al., $(2006)^{50}$ worked on biochemical composition of Atlantic bonito (Sarda sarda) at different stages of maturity. Highest lipid levels in white muscle and liver were measured in immature specimens while lowest in spawning bonitos and decrease in protein content was observed in spawning bonitos.

Hormones show an effect on biochemical fluctuations in fish tissues. Joernsson (1997) ${ }^{51}$ stated the growth hormone stimulates protein synthesis, promotes lipid and glycogen breakdown and gluconeogenesis with an increase in growth hormone levels. Cartee et al., (2000) ${ }^{52}$ observed elevated levels of amino acid in pylorus, liver and white muscle at different times of protein synthesis in Atlantic salmon. Sunde et al., (2001) ${ }^{53}$ revealed a negative correlation indicating increased growth rate was not caused by increased protein deposition rate in Atlantic salmon.

Temperature fluctuations affect the biochemical levels in the fish. Morgan et al., (1998) ${ }^{54}$ worked on the effect of elevated water temperature and sub lethal pollutants on gill and liver which resulted in elevation of gill protein synthesis and decrease in protein synthesis at control temperatures in gill and liver of rainbow trout. Martinez et al., (1999) 55 stated that the increase in muscle aerobic capacity and protein contents accompanied the decrease in temperatures from September to December in Atlantic cod. Olsen et al., (1999) ${ }^{56}$ made 
observations on the influence of temperature on fatty acid composition and indices of oxidative stress in juvenile Arctic char. Newsted and Giesy $(2000)^{57}$ stated that the binding of Epidermal Growth Factor to hepatic membranes are temperature dependent and resulted in increased phosphorylation of membrane components in rainbow trout.

According to Sobha et al., (2007) ${ }^{58}$ the levels of glucose, glycogen, total proteins, lipids and free amino acids in tissues of muscle, gill, heart, liver and kidney exposed to cadmium chloride show sub lethal concentrations of fall except glucose indicative of the organisms' response to toxicant stress. Seasonal changes effect on the biochemical constituents. Lund et al., (2000) $)^{59}$ stated at the total protein levels and plasma lipid showed fluctuations according to seasonal changes in both males and females of striped bass. Nordgarden et al., (2003) ${ }^{60}$ stated that fatty acids are low during early spring and increased slowly and during spring in Atlantic salmon.

In the present study, lipids, proteins and carbohydrates were observed in seasonal wise in the fish, G. achlamys and A. indica. Overall, biochemical constituents were more in $A$. indica when compare with G. achlamys.

\section{References}

1. Saha K.F. and Guha B.C. Nutritional investigation of Bengal fish. Indian J. Med. Res. 27 (1940): 873876.

2. George M.G., Qasim S.Z. and Siddiqui A.Q. A limnological survey of the river Kali with reference to fish mortality. Enviro. Hlth. 8.4 (1966): 262-269.

3. Sivani, G. Studies on biology, nutritive value and fishery of some commercially important fishes of Gostani estuary near Visakhapatnam. Ph.D. thesis submitted to Andhra University, Waltair, India (1994).

4. Rao P.S. and Rao L.M. Variations in bio-chemical composition of Glossogobius giuris (Hamilton) from Gosthani with observation on distribution (Caranx sexfasciatus host India). Curr. Sci., 35.4 (2002): 101-102.

5. Palace V.P., Tomy G.T., Evans R.E., Wautier K., Danell R.W., Halldorson T. and Braekevlt E. Biochemical effects of dietary exposure to polybrominated diphenyl ethers in juvenile lake trout, meeting Abstract (2003): 95-96.

6. Vaulyeva O.B., Sidorov V.S., Lizenko K.I. Lipid composition of Lipoproteins in female rainbow trout Salmo gairelnerii in annual cycle. Journal of Ichthgology 44.4 (2004): 122-126.

7. Zaboukas N., Miliou H., Megalofunou P. and Maraitou Apostolopoulou M. Biochemical composition of the Atlantic bonito, Sarda sarda from the Aegean Sea in different stages of sexual maturity. Journal of fish biology 69 (2006): 347-362.

8. Sobha K., Porinima A., Harini P. and Veeraiah K. A study on biochemical changes in the freshwater fish, Catla catla (Hanailton) exposed to the heavy metal toxicant Cadmium Chloride. Kathmandu University Journal of Science, Engineering and Tecbnology I. IV (2007): 147-149.

9. Douglas R., Eldar A., Patrick J., Campbell B. and Gordon Bell J. The role of phospholipids in nutrition and metabolism of teleost fish. J. Aqaculture 280.1-4 (2008): 21-34.

10. Lowry O.H., Rose Browgh N.J., Farr A.L. and Randall R.J. Protein measurement with folin phenol reagent. J. Biol. Chem. 193 (1951): 265-275.

11. Dubois M., Gilles K.A., Hamilton J.K., Rebers P.A. and Smith F. Calorimetric method for determination of sugars and related substances. Anal. Chem. 28 (1956): 350-356.

12. Folsch J., Less M. and Slonae Stanley G.H. A simple method for isolation and purification of total lipids from animal tissues. J. Biol. Chem. 226 (1957): 497-507.

13. Ravisankar pisca and Sarala Waghray. Biochemical variations of reproductive tissues of Amblypharyngodon mola (Ham.) with reference to spawning cycle. Indian. J. fsh 36.4 (1989):247-251.

14. Sowmya shree S., Tharavathy, N.C., Reema, L. and Shafakatullah, N. Seasonal changes in the biochemical composition of freshwater bivalves, Parreysia spp. From Tungabhadra river, Karnataka. International Journal of Pharma Sciences and Research 4.5 (2013): 94-99.

15. Rajendra Shejwal, Ramrao Patil and Shivdas N. Biochemical Analysis to Study the Nutritive Value of the Fish Catla Catla after Exposure to the Phytotoxin from Lasiosiphon Eriocephalus. International Conference on Trends in Economics, Humanities and Management, Aug 13-14, Pattaya (Thailand) (2014): 203-204

16. Nadia Ullah, Prashun Hazarika, Pratap Jyoti H. Biochemical Quality Assessment of Ten Selected Dried Fish Species of North East India. International Advanced Research Journal in Science, Engineering and Technology 3.1(2016): 30-33.

17. Jacquot R. Organic constituents of fish and other aquatic animal foods. In: Fish as food (Ed. George Borgstrom). Academic Press. Inc. N.Y. (1961): 122-127.

18. Saha K.F. and Guha B.C. Nutritional investigation of Bengal fish. Indian J. Med. Res. 27 (1940): 873-876.

19. Venkataramana, $\mathrm{R}$ and Chari S.T. Seasonal variations in the fat of mackerel, Rastrelliger Kanagurtha. Proc. Ind. Acd. Sci. 33(A) (1951): 126-133. 
20. Chidambaram K., Krishna Murthy G. Venkataramana R. and Curi S.T. Studies on marked fat Variations and Certain Biological aspects. Proc. Ind. Acad. Sci. 35(B) (1952): 43-68.

21. Hornung H., Sukenik A. and Gabrielides G.P. Distribution and composition of fatty acids in muscle lipids of inshore fish and deep-water sharks from the eastern Mediterranean. Mar. Pollut. Bull. 28. 7 (1994): 448-450.

22. Jeong B.Y., Choi B.D., Moon S. and Lee J.S. Fatty acid composition of 72 species of Korean fish. Journal of fisheries science and technology 1.1 (1998): 129-146.

23. Clavijo I.E., Dunn C.S. and Seaton P.J. Preliminary Study of Lipid Content and Fatty Acid Composition in the Spottail Pinfish, Diplodus bolbrooki. Copeia 3 (1999): 766-771.

24. Wang B.O. Liu S., Zhuo Y., Zhang Z. and Zhaohui $Z$. Biochemical composition and its prediction model of red drum (Sciaemps ocellatus). Advances in Marine Science 20.4 (2002): 56-61.

25. Kamler E. Antarctic fishes: the chemical composition of muscle, liver and food of two Notothenioids. Archives of Polish fisheries. Arch. Pol. Fish 11.2 (2003): 197-206.

26. Wagner G.N., Balfry S.K., Higgs D.A., Lall S.P. and Farrell A.P. Dietary fatty acid composition affects the repeat swimming performance of Atlantic salmon in seawater. Comparative Biochemistry and Physiology-Part A: -Molecular and Integrative Physiology 137.3 (2004): 567-576.

27. Saha K.C. and Guha B.C. Nutritional Investigations on Bengal Fish. Ind. J.Med.Res. 26 (1939): 921-927.

28. Satti Reddy K. Comparative studies on the ecology and biology of Mystus species (Telecostei: Bagriolae) from Mehadrigedda stream of Visakhapatnam. Ph.D. Thesis submitted to the Andhra University, Waltair, India (1992).

29. Love R.M. The chemical biology of fishes. London Academic Press (1970): 547.

30. George M.G., Qasim S.Z. and Siddiqui A.Q. A limnological survey of the river Kali with reference to fish mortality. Enviro. Hlth. 8.4 (1966): 262-269.

31. Hickling C.F. The seasonal cycle in the corn fish pilchard, Sardina pilchardu Wolf. J. Mar. Biol. Ass. U.K. 21 (1947): 115-138.

32. Ehrlich K.F. Chemical changes during growth and starvation of larval Pleuronectes platessa. Mar. Biol . 24 (1974): 34-48.

33. Anderson R.M. and May R.M. Population biology of infectious diseases: Part 1. Nature, 280 (1979): 361-367.

34. Siva Kami R., Prem Kishore G. and Chandran M.R. Effect of chromium on the metabolism and biochemical composition of selected tissues in the fresh water cat fish Mystus vittatus. Environ. Ecol. 12 (1994): 259-266.

35. Reddy M.S. and Ramana Rao K.V. Glucose Metabolism in selected tissues of penacid prawn Penaeus indicus during lethal and sub-lethal phosphamidon induced stress. Ind. J. Mar. Sci. 14 (1985): 244-255.

36. Davis D.A., Lazo, J.P. and Arnold C.R. Response of juvenile red drum (Sciaenops ocellatus) to practical diets supplemented with medium chain triglycerides. Fish Physiology and Biochemistry 21.3 (1999): 235-247.

37. Olsen R.E., Loevaas E. and Lie O.E. The influence of temperature, dietary polyunsaturated fatty acids, alpha-tocopherol and spermine on fatty acid Composition and indices of Oxidative stress in juvenile Arctic Char. Fish Physiology and Biochemistry 20.1(1999): 147-151.

38. Bell J.G., Tocher D.R., Farndale B.M., Mc. Vicar A.H. and Sargent J.R. Effects of essential fatty acid deficient diets on growth, mortality, tissue histopathology and fatty acid compositions in Juvenile turbot. Fish Physiology and Biochemistry 20.33 (1999): 263-277.

39. Gunasekara R.M., De-Silva S.S. and Ingram B.A. Chemical changes in fed and starved larval trout cod. Maccullochella macuarensis during early development. Fish Physiology and Biochemistry 25.4 (2001): 255-268.

40. Abdullahi S.A. Investigation of nutritional status of Chrysichthys nigrodigatus, Bagrus filamintosus and Auchenoglanis occidentalis. Family Bagridae. Journal of Arid zone fisheries 1 (2001): 39-50.

41. Mourente G. and Dick J.R. Influence of partial substitution of dietary fish oil by vegetable oils on the metabolism of $18 ; 3 \mathrm{n} .3$ in isolated hepatocytes of European sea bass. Fish Physiology and Biochemistry 26.3 (2002): 297-308.

42. Kirchner Severine, Stephane Pansera and Sadasivam Kaushik. Low level of dietary protein is associated with reduced hepatic gluconeogenic enzyme expression in rainbow trout (Oncorbynchus mykiss). Fish Physiology and Biochemistry 55. 6 (2003): 152-157.

43. Southgate P.C., Lee P.S. and Rinmer M.A. Growth and biochemical composition of cultured seabass. Asian fisheries science. Metromanila. Asian Fish. Sci. 7.4(1998): 241-247.

44. Carpene E., Martin B. and Libera L.D. Biochemical differences in lateral muscle of wild and farmed gilthead sea bream (sparus aurata L.). Fish Physiology and Biochemistry 19.2 (1998): 229-238.

45. Izquierdo M., Obach A., Arantzamendi L., Montero D., Robaina L. and Rosenlund G. Dietary lipid sources for seabream and seabass: growth 
performance, tissue composition and flesh quality. Aquaculture Nutrition 9.6 (2003): 397-407.

46. Ingermann R.L., Johnson D.C. and Gloucs J.G. Low seminal plasma buffering capacity corresponds to high $\mathrm{PH}$ sensitivity of sperm motility in salmonicids. Fish Physiology and Biochemistry 24.4 (2001): 299-307.

47. Mourente G., Megina C. and Diaz-Salvgo E. 2001. Lipids in female northern bluefin tuna (Thunnus thynnus thynnus L) during sexual maturation. Fish Physiology and Biochemistry 24.4 (2001): 351-363.

48. Sebetes A., Rossi S. and Reyes E. Lipid content in early life stages of three mesopelagic fishes. Journal of fish biology 63 (2003): 881-891.

49. Vasualyeva O.B., Sidorov V.S. and Lizenko K.I. Lipid composition of Lipoproteins in female rainbow trout Salmo gairelnerii in annual cycle. Journal of Ichthyology 44.4 (2004): 144-149.

50. Zaboukas N., Miliou H., Megalofunou P. and Maraitou Apostolopoulou M. Biochemical composition of the Atlantic bonito, Sarda sarda from the Aegean Sea in different stages of sexual maturity. Journal of fish biology 69 (2006): 347-362.

51. Joernsson B. The biology of salmon growth hormone. From daylight to dominance. Fish Physiology and Biochemistry 17.1-6 (1997): 9-24.

52. Cartee C.G., Houlihar D.F. and Zy H.E. Charges in tissue free aminoacid concentration in Atlantic salmon, Salomo Salar L. Fish Pby \& Biochem. 23.4 (2000), 295-306.

53. Sunde J., Taranger G.L. and Rungruanysak Torrissen K. Digestive proteage activity and free aminoacids in white muscle as Indications for feed conservation efficiency and growth rate in Atlantic salmon (Salmo salar L.) Fish Physiology and Biochemistry 25.4 (2001): 335-345.

54. Morgan I.J., Cruz D., Dockrat J.J., Dockray J.J., Linton T.K., Mc Donald D.G. and Wood C.M. The effects of elevated winter temperature and sublethal pollutants on Protein turnover in the gill and liver of rainbow trout. (Oncorbychus mykiss). Fish physiology and Biochemistry 19.4 (1998): 178-184.

55. Martinez M., Couture P. and Guderley H. Temporal changes in tissue metabolic capacities of wild Atlantic cod Gadus morbua (L.) from New found land. Fish Physiology and Biochemistry 20.2.2(1999): 199-204.

56. Olsen R. E., Loevaas E. and Lie O.E. The influence of temperature, dietary polyunsaturated fatty acids, alpha- tocopherol and spermine on fatty acid Composition and indices of Oxidative stress in juvenile Arctic Char. Fish Physiology and Biochemistry 20.1 (1999): 201-207.

57. Newsted J.L. and Giesy J.P. Epidermal growth factor receptor protein kinase interactions in hepatic membranes of rainbow trout. Fish Physiology and Biochem. 22.3 (2000): 181-189.

58. Sobha K., Porinima A., Harini P. and Veeraiah K. A study on biochemical changes in the freshwater fish, Catla catla (Hanailton) exposed to the heavy metal toxicant Cadmium Chloride. Kathmandu University Journal of Science, Engineering and Technology I.IV (2007): 14-22.

59. Lund E.D., Sullivan C.V. and Place A.R. Annual cycle of plasma lipids, proteins in captive reared striped bass. Fish physiology and Biochem. 22.3 (2000): 263-275.

60. Nordgarden U.B., Torstensen E., Froyland T., Hansen G. and Hemre I. Seasonally changing metabolism rate in Atlantic salmon (Salmo salar, L.) 2. B-oxidation capacity and fatty acid composition in muscle tissues and plasma lipoproteins. Aquaculture nutrition 9.5(2003): 295-303.

\section{Cite this article as:}

Siva Prasad K., Prasad. N.V., Ch. Venkateswarlu. Seasonal variations in the biochemical composition of muscle and liver of marine fishes, Gazza achlamys and Ariomma indica from Visakhapatnam coast, South India. International Journal of Bioassays 6.6 (2017) pp. 5407-5414.

DOI: http://dx.doi.org/10. 21746/ijbio.2017.06.005

\section{Source of support: Nil \\ Conflict of interest: None Declared}

